\title{
THE EFFECT OF STEPWISE EXERCISE ON SOME CARDIORESPIRATORY FUNCTIONS IN SPORT HORSES
}

\author{
J. HANÁK \\ Department of Diagnosis, Therapy and Control of Animal Diseases, University of Veterinary
} Science, 61242 Brno

Received March 11, 1989

\begin{abstract}
Hanák J.: The Effect of Stepwise Exercise on Some Cardiorespiratory Functions in Sport Horses. Acta vet. Brno, 59, 1990: 41-49.

Heart frequency $\left(f_{H}\right)$ and total minute oxygen uptake $\left(\mathrm{V}_{0_{2}}\right)$ were radiotelemetrically studied in 12 horses, ranging in age from 4-12 years, at stepwise exercise. From the obtained results the value of the so-called pulse oxygen $\left(T_{02}\right)$ representing the amount of $\mathrm{O}_{2}$ transported by one heart systolic volume was determined.

The dependence of the oxygen uptake upon exercise was linear. A positive correlation is given by very close coefficients of correlation $(r=0.99$ and 0.97$)$. The value of pulse oxygen was, however, in a parabolic dependence not only on the speed but also on the heart rate and oxygen uptake. The steepest increase of the $\mathrm{T}_{0_{2}}$ ) was found to be up to $f_{H} 170$ and up to the speed of $500 \mathrm{~m} / \mathrm{min}$. If the oxygen consumption is higher than $55 \mathrm{l} / \mathrm{min}$, corresponding thus to work effort (WE) of $70 \%$ max., the $\mathbf{T}_{02}$ was found to decrease.
\end{abstract}

Horse, exercise, walk, trot, cauter, gallop, pulse oxygen

Exercise of a horse places heavy demands on the cardiovascular system as far as blood volume and pressure are concerned. The former are associated with energy demands and large respiratory gas exchange. The pressure demands follow from the need to sustain the circulatory balance in the whole organism. Exercise places heavy demands also upon the thermoregulatory processes where not inconsiderable role is played also by cardiovascular system, or the distribution of the cardiac output, in order to ensure the thermoregulation requirements of a working organism.

The efficiency of the cardiovascular system and functions at horse exercise has already been discussed in several excellent review (Engelhardt 1977; Holmes 1982; Fregin and Thomas 1983; Physick-Sheard 1985; Rose and Evans 1987). From these studies follows that the oxygen uptake is determined by parameters of circulation, i. e. the value of cardiac output $(Q)$, given as a product of stroke volume $\left(Q_{S}\right)$ and heart frequency $\left(f_{H}\right)$ (that is the central component) and by hemoglobin content and changes in the vessel bed including arteriovenous oxygen difference $\left(\mathrm{C}_{\mathrm{a}_{02}}-\mathrm{C}_{\mathrm{V}_{02}}\right)$ (that is the peripheral component). This can be expressed by the equation

$$
\mathrm{VO}_{2}=\mathrm{Q} \cdot\left(\mathrm{Ca}_{02}-\mathrm{Cv}_{0_{2}}\right)=\mathrm{Q}_{\mathrm{s}} \cdot \mathbf{f}_{\mathrm{H}} \cdot\left(\mathrm{Ca}_{02}-\mathrm{Cv}_{0_{2}}\right)
$$

The presented interpretation assumes that the respiratory system itself is not a limiting factor of maximal aerobic performance of a horse but that this performance is conditioned first of all by cardio respiratory functions, i. e. by the value of cardiac output and the degree of oxygen desaturation of blood (Gillespie 1974; Gillespie and Pascoe 1983). At present, disputes are very lively about the significance and changes of the stroke volume during exercise. A great role has been attributed to the blood transport capacity and to the spleen as a red cell reserve for peripheral circulation at exercise (Persson 1967; Persson et al. 1973a, b; Persson and Bergsten 1975).

The aim of the present study has been to evaluate the dynamics of some cardiorespiratory functions during the stepwise exercise in sport horses as a suitable criterion for an assessment of fitness. 


\section{Materials and Methods}

Altogether 12 sport horses, ranging in age from 4-12 years, weighing in average $477.5 \pm 32.8 \mathrm{~kg}$, were used in the experiment. Horses were ridden by $70-80 \mathrm{~kg}$ weighing riders and were subjected to a $3000 \mathrm{~m}$ exercise at the walk, trot and gallop. The speed of these rates represented in every horse 15, 30 and $50 \%$ of horses' individual utmost speed (WE max) measured with identical riders in a pre-trial at the $400 \mathrm{~m}$ distance. Further 6 horses selected from this set were subjected on a following day to further exercise $(1500 \mathrm{~m}$ distance), the speed corresponding to $70 \%$ of the maximum work effort of every horse ( $\% \mathrm{WE} \max )$.

Using a radiotelemetrical method (Hanák and Zakopal 1979; 1980; Hanák 1980) heart frequency $\left(f_{H}\right)$, breathing frequency $\left(f_{b}\right)$ and tital volume $\left(V_{T}\right)$ were monitored at rest and at four types of exercise. Multiplying the $f_{b}$ and $V_{T}$ values the minute pulmonary ventilation $\left(V_{E}\right)$ was calculated and then tabularly corrected to the BTPS conditions. The percentage of $0_{2}$ uptake was determined on a Scholander instrument from the analysis of atmospherical and expired air samples collected from the respiration mask by a special five-port collector and then tabularly corrected to the STPD conditions. From the $V_{E}$ value and from the percentage of oxygen uptake the value of total oxygen uptake per minute $\left(\mathrm{VO}_{2}\right)$ was determined. This value divided by that of heart frequency $\left(f_{H}\right)$ expressed the value of the so called pulse oxygen $\left(\mathrm{T}_{2}\right)$ representing the amount of 0 , transported by one stroke volume $\left(Q_{s}\right)$.

The results were statistically and graphically processed on a model $9810 \mathrm{~A}$ Hewlett-Packard computer. The method of a simple analysis of variance and Duncan's test were used to analyze the statistical significance of set differences. The closeness of the relationship was expressed by coefficient of correlation $(r)$, the dependence between the studied values by regression equations.

\section{Results}

From Fig. 1 follows that heart rate is linearly dependent upon the exercise speed. A positive correlation is given by a very close coefficient of correlation $(r=$ $=0,997$ ) and by regression equation of the straight line presented in Table 1 .

The dependence of oxygen uptake $\left(\mathrm{VO}_{2}\right)$ on the heart frequency $\left(f_{H}\right)$ was found to be also linear as can be seen from Fig. 2. It is expressed by regression equation of the straight line at a very close positive relationship (Table 1). The value of pulse oxygen $\left(\mathrm{TO}_{2}\right)$ was, however, found to be in parabolic dependence both on

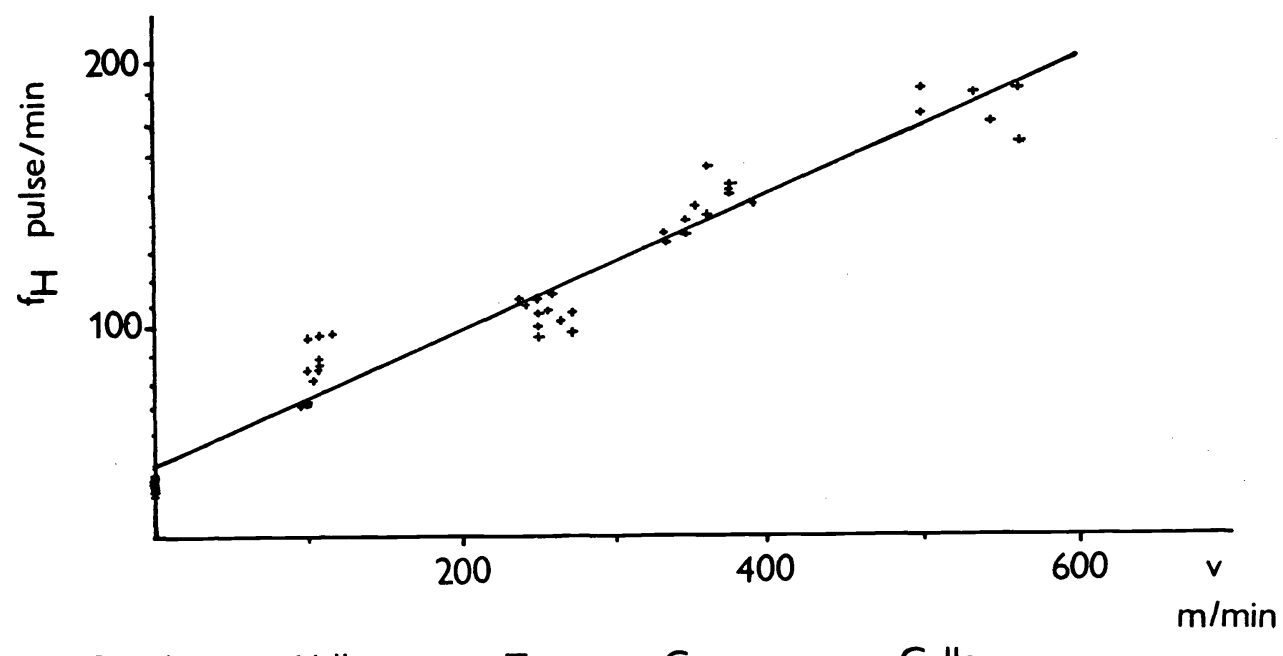

Standing Walk Trot Canter Gallop

Fig. 1, 
heart frequency (Fig. 3) and exercise speed (Fig. 4) and thus also on exerted work effort (WE). The relationship is expressed by regression equations and coefficients of correlation in Table 1, the latter ones being somewhat broader. From Figs. 3 and 4 is evident that the steepest increase of the $\mathrm{TO}_{2}$ value is observed up to $f_{H}$ 170 and speep of $500 \mathrm{~m} / \mathrm{min}$. At higher heart frequency and speeds the increase of $\mathrm{T}_{2}$ values is already very low. Due to the parabolic dependency it can be assumed that the $\mathrm{TO}_{2}$ at high heart frequency can even drop.

The above-mentioned assumption can also be confirmed by a parabolic dependence of $\mathrm{TO}_{2}$ on the $\mathrm{VO}_{2}$ value in Fig. 5 that is given by a regression equation and by even closer positive correlation (Table 1). An apparent tendency to a decrease of $\mathrm{TO}_{2}$ at $\mathrm{VO}_{2}$ higer than $55 \mathrm{l} / \mathrm{min}$, corresponding to work effort higher than $70 \%$ of the maximum, is evident from the figure.

Table 1

Dependence between the speed ( $v)$, heart rate $\left(\mathrm{f}_{H}\right)$ oxygen uptake $\left(\mathrm{VO}_{2}\right)$ and the value of pulse oxygen $\left(\mathrm{TO}_{2}\right)$ expressed by regression equations and coefficients of correlation

\begin{tabular}{|l|l|l|}
\hline \multicolumn{1}{|c|}{ Dependence } & $\mathrm{r}$ & $\mathrm{P}$ \\
\hline$f_{H}=46.9429+0.2578 \cdot v$ & 0.97 & 0.01 \\
$V_{0_{2}}=0.79+0.10 \cdot v$ & 0.99 & 0.01 \\
$V_{0_{2}}=-16.1394+0.3783 \cdot f_{H}$ & 0.97 & 0.01 \\
$T_{0_{2}}=47.853+0.8895 \cdot v-0.00075 \mathrm{~m} \cdot v^{2}$ & 0.86 & 0.01 \\
$T_{0_{2}}=88.250+3.60 \cdot f_{H}-0.01 \cdot f_{H}^{2}$ & 0.82 & 0.01 \\
$T_{0_{2}}=30.950+10.16 \cdot V_{0_{2}}-0.10 \cdot V_{0_{2}}$ & 0.95 & 0.01 \\
\hline
\end{tabular}

\section{Discussion}

The uptake of oxygen $\left(\mathrm{VO}_{2}\right)$ and the efficiency of its transport from lungs to the mitochondrial system of working tissues is summarily expressed by the oxygen pulse value $\left(\mathrm{TO}_{2}\right)$. It represents the amount of oxygen delivered into the circulation and transported by one systolic volume. Thus, it is an indicator of the efectiveness of cardiovascular system work at oxygen transport and, indirectly, also the indicator of stroke volume changes $\left(Q_{s}\right)$ at exercise (Wasserman and Whipp 1975). It also informs how the organism compensates for the increased hemodynamic requirements of exercise by the increase of either heart rate or stroke volume:

A whole series of factors that increase the oxygen transport capacity of the cardiovascular system can contribute to the $\mathrm{TO}_{2}$ elevation during exercise. The decisive factors in the increase of $\mathrm{TO}_{2}$ are, however, oxygen uptake $\left(\mathrm{VO}_{2}\right)$ and stroke volume $\left(Q_{s}\right)$. Also the quality of red blood cell turnover ( $\mathrm{Er}, \mathrm{Hb}, \mathrm{HK}$ ), limiting the hemoglobin binding capacity for oxygen and thus other parameters of blood gas transport, contribute in a high degree to the elevation of $\mathrm{T0}_{2}$. It can thus be concluded that changes in $\mathrm{TO}_{2}$ during exercise correspond closely with the changes of oxygen uptake, stroke volume, mobilization of splenic red cell reserve and also with the fluid shift between intravasal and extravasal spaces.

The dependence of $\mathrm{TO}_{2}$ upon exercise intensity, heart rate and oxygen uptake is parabolic. The steepest increase in the $\mathrm{TO}_{2}$ value was found at heart rate up to about 170 beats $/ \mathrm{min}$, speed of $500 \mathrm{~m} / \mathrm{min}$ and $\mathrm{VO}_{2} 50 \mathrm{l} / \mathrm{min}$. At higher intensity of exercise with working effort WE $=70 \% \max$, represented by $f_{H}=170-200$ beats $/ \mathrm{min}, \mathrm{v}=500-600 \mathrm{~m} / \mathrm{min}$ and $\mathrm{VO}_{2}=55 \mathrm{l} / \mathrm{min}$, the increase of $\mathrm{TO}_{2}$ was 

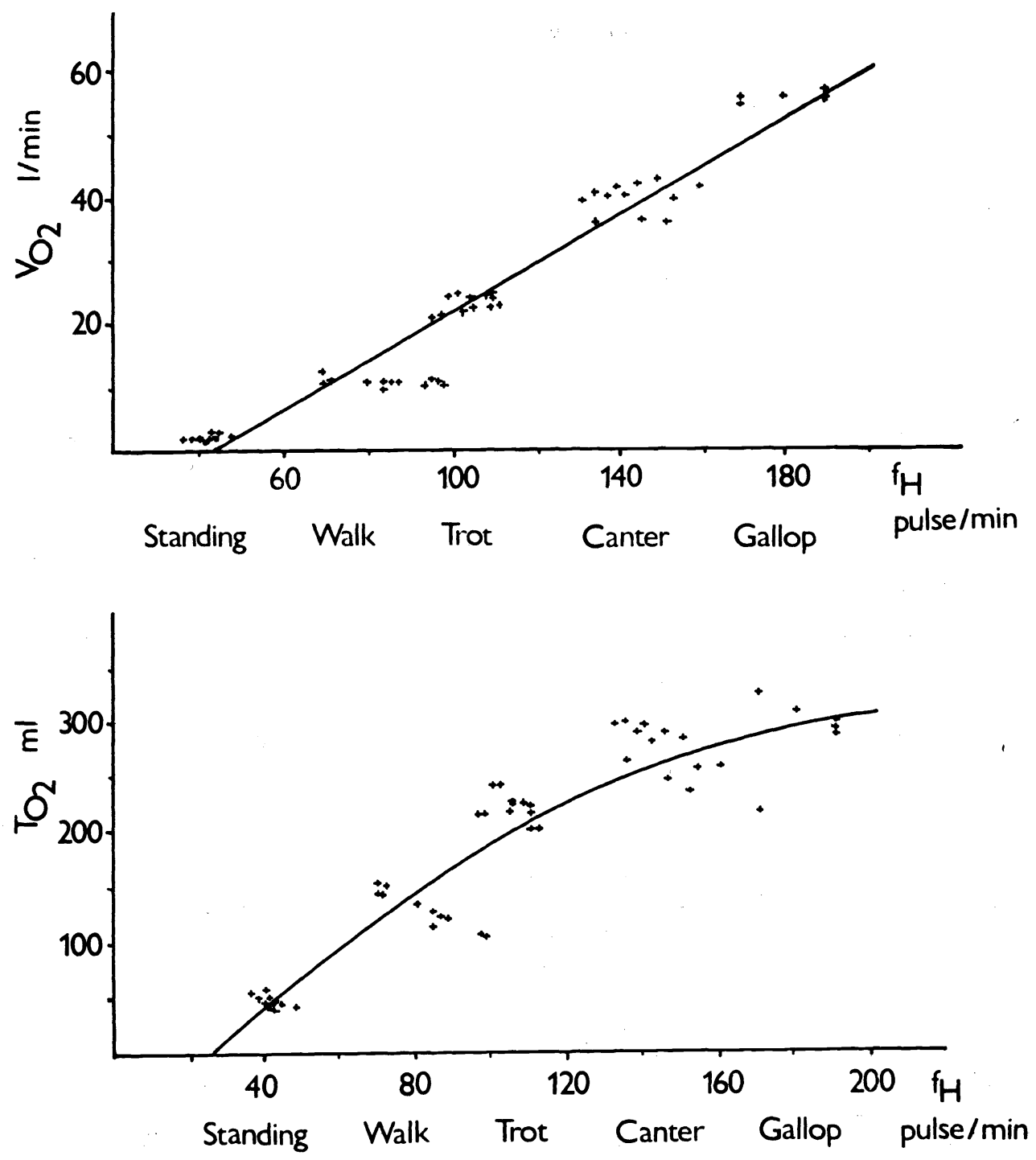

F. 2. (top) and Fig. 3. (bottom).

found to be very slight. It can thus be concluded that at exercise intensity over $70 \%$ WE max the higher oxygen transport to tissues is provided not by the elevation of $\mathrm{TO}_{2}$ but by that of $f_{H}$. A question thus aries what caused this relative stabilization of $\mathrm{TO}_{2}$ at WE $70 \%$ max?

On one hand, this $T_{0_{2}}$ stability at WE $70 \% \max$ could be associated with the arrival to the maximum rate of oxygen consumption $\left(V_{0_{2}} \max \right)$ when the oxygen uptake does not increase any more. From our preceding study on ventilatory equivalent changes and $0_{2}$ utilization from inspired air (Hanák 1987) follows that the restriction of oxygen uptake occurs at intensities higher than $70 \%$ 
WE max as well. The limit of $T_{0_{2}}$ stabilization and of the restriction of oxygen uptake is thus approximately indetical. From that the answer to the above placed question could be obtained that at exercise with work effort of $70 \%$ WE max the $T_{0_{2}}$ max is achieved, being conditioned by the oxygen uptake near $V_{0 \mathrm{~s}}$ max. Heart rate $170-200$ beats $/ \mathrm{min}, v=500-600 \mathrm{~m} / \mathrm{min}$ and $V_{02}$ at about $551 / \mathrm{min}$ correspond to this limit in sport horses.

On the other hand, the relative stabilization of $\mathrm{T0}_{2}\left(\mathrm{T0}_{2} \mathrm{max}\right)$ at the limit of $70 \%$ WE max could also be caused by the so called regulatory heart dilatation and a maximum stroke volume $\left(Q_{s} \max \right)$. It would not only confirm the above presented fact that higher oxygen transfer to tissues is, starting from the mentioned level, ensured by the increase in heart frequency only but also that the total hemodynamic requierements upon the elevation of cardiac output $(Q)$ are at higher exercise intensity ensured only by the increase of heart frequency at $Q_{\delta}$ max or even lower (Engelhardt 1977). To this effect, $\mathrm{T}_{2}$ would also inform indirectly about the economy of heart work as was reported by Wasserman and Whipp (1975).

The problem has not been solved of how and how much the stroke volume increases in horses at stepwise exercise, the literature data on $Q_{s}$ changes during exercise being very diverse (Rose and Evans 1987; Evans and Rose 1987). Taking into account the finding of Thomas and Fregin (1981) we can see that the increase in $Q_{s}$ represents $41 \%$ of the rest value (i. e. 1.5 fold). If we compare this result with the 6-times increased value of $\mathrm{TO}_{2}$ confronted with the rest value obtained by us then it is obvious that oxygen uptake, or other factors ensuring the oxygen transport from lungs to working tissues, participate in a higher degree than the rise in $Q_{8}$ in the increase of $\mathrm{TO}_{2}$ at stepwise exercise of horses. It is predominantly the splenic red cell reserve mobilization that is induced by exercise at heart frequency higher than 100 beats/min. (Perss on 1967, 1969). Hemoconcentration with the elevated $\mathrm{Er}, \mathrm{Hb}$ and $\mathrm{HK}$ values is further deepened by the plasma volume tissues (Wittke et al. 1974; Carls on 1983, 1987). Thus the conditions for a higher oxygen uptake and for a $T_{0 s}$ rise up to the $70 \%$ WE max are formed. Together with the significant $Q_{\delta}$ increase they represent high economy of heart

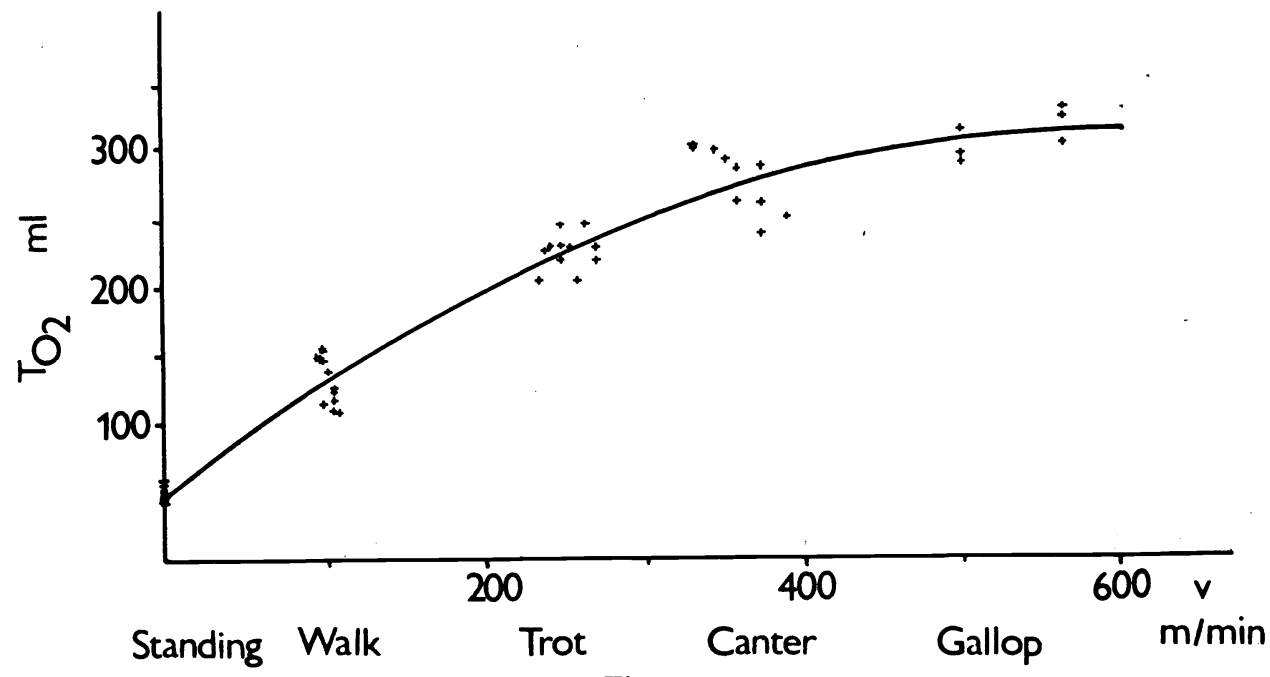

Fig. 4. 


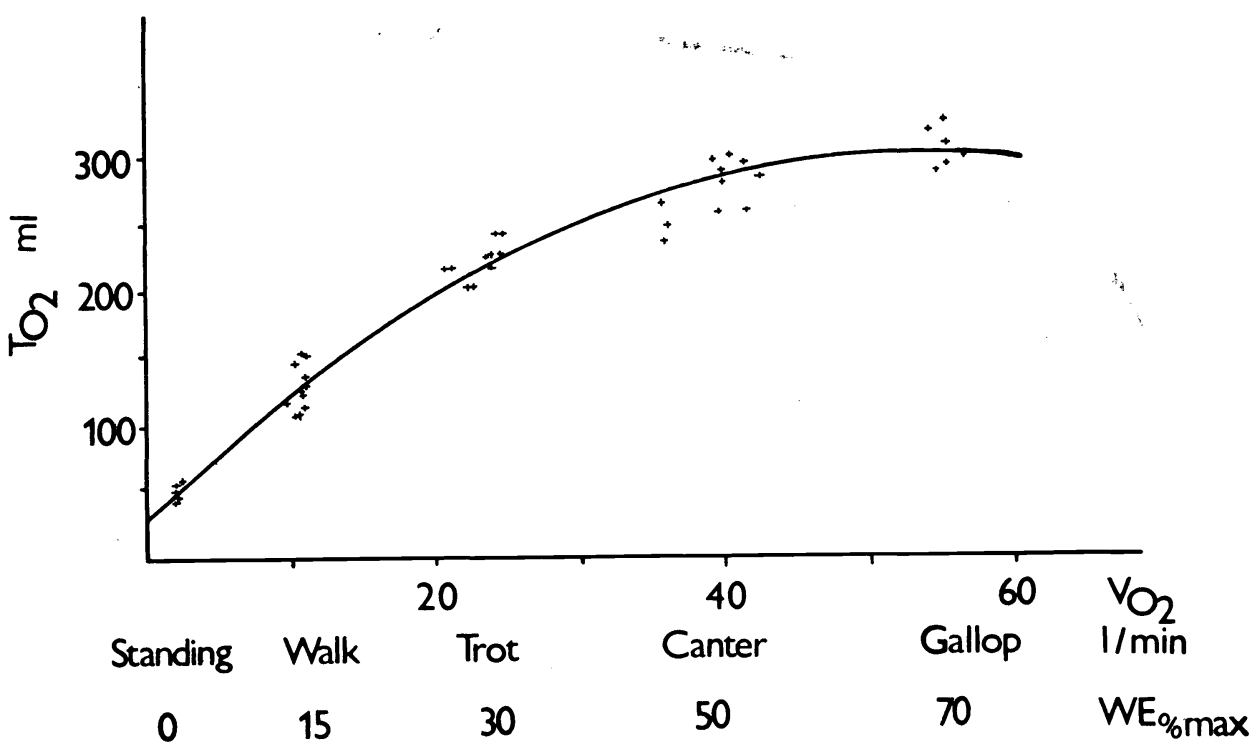

Fig. 5.

work at $f_{H} 170-200$ beats $/ \mathrm{min}$. If the increase in $Q_{\delta}$ at intensified exercise compared with the rest value is identical both in man and horses $\left(1.5\right.$ fold) then the $T_{0_{2}}$ increase in the horse represents $0.6-0.8 \mathrm{ml} / \mathrm{kg} \mathrm{b}$. w., being two times higher than that in $\operatorname{man}(0.35 \mathrm{ml} / \mathrm{kg} \mathrm{b}$. w.). This presentation shows a doubled capacity of an oxygen uptake transport system in horses compared to man. It has also been confirmed by Engelhardt (1977) or McMiken (1983) that a horse increases the oxygen consumption compared with the rest 35-40 times whereas in man it is only 20 times, i. e. two-fold increase. This capability of a horse is given predominantly by a high efficiency of respiratory functions and by a function of circulatory system, including the mobilization of splenic reserve.

With regard to the described significant effect of $\mathrm{TO}_{2}$ upon $\mathrm{TO}_{2}$ it can be assumed that after reaching the maximum rate of oxygen consumption the $\mathrm{T}_{2}$ value at exercise intensity higher than $70 \%$ WE max begins to decrease at higher $f_{H}$. It follows from Fig. 5 that a pronounced drop of $\mathrm{TO}_{2}$ at $\mathrm{VO}_{2}$ of about $55 \mathrm{l} / \mathrm{min}$ and more occurs. It can thus be concluded that either $\mathrm{VO}_{2}$ value of $55 \mathrm{1} / \mathrm{min}$ is the limit of the maximum rate of oxygen consumption and $\mathrm{T}_{2}$ drops after reaching this value, or that other factors than $\mathrm{VO}_{2} \max$ participate in $\mathrm{TO}_{2}$ decrease. In the latter case the primary role would be played by the reduction in stroke volume, similarly as in man (Wasserman and Whipp 1975). This would occur particularly if the upper anaerobic threshold is exceeded at $f_{H}$ of about 200 beats $/ \mathrm{min}$. (Persson 1983; McMiken 1983; Physick-Sheard 1985) when the diastolic filling time is extremely shortened (Senta et al. 1970; Engelhardt 1977; Hanák $1980,1987)$. This latter theory appears to be more probable due to the presented parabolic dependence of $\mathrm{TO}_{2}$ upon $\mathrm{VO}_{2}$ shown in Fig. 5, i. e. that $\mathrm{TO}_{2}$ decreases at $\mathrm{VO}_{2}$ still rising.

In performing individuals $\mathrm{TO}_{2}, \mathrm{VO}_{2}$ and $Q_{s}$ are generally higher and that is the reason why they do not increase heart frequency up to maximum values but closely over the limit of anaerobic threshold of $200-210$ beats $/ \mathrm{min}$ at sub- 
maximal and particularly maximal exercise. It seems to be logical because performing horses at relatively identical speeds have higher $Q_{s}$ and lower $f_{H}$ (Ehrlein 1970; Engelhardt 1977; Hanák 1980, 1987), reaching thus at higher $\mathrm{VO}_{2}$ (Evans and Rose 1987) also a higher $\mathrm{TO}_{3}$ (Hörnicke et al. 1983). The last mentioned author reported in individual cases a close relationship between more rapid and higher $\mathrm{TO}_{3}$ increase and horse performance.

Our finding obtained particularly at gallop confirms this, as can be seen from Fig. 3 and 4 . It can be concluded that more trained individuals have, owing to higher $\mathrm{VO}_{2}$ max and better heart work economy, also a higher aerobic capacity and maximal aerobic performace which at maximum exercise irepresent a lower increase in $f_{H}$ and lower number of heart beats per exerted work. This has also been confirmed by the results of radiotelemetrical recording of $f_{H}$ during races reported in our preceding study (Hanák 1987).

From the above presented a very importance fact arises that the maximum utilization of oxygen from expired air and the maximum $\mathrm{TO}_{2}$ and $Q_{s}$ values are reached at approximately identical heart frequency of $170-200$ beats/min, to which the exercise intensity representing $70 \%$ WE max corresponds. At higher exercise intensity and heart rate a further increase of cardiac output for ensuring the hemodynamics and further higher transport of oxygen to working tissues is realized only by an economically less effective increase of heart frequency. $\mathrm{TO}_{2}$ and $Q_{s}$ are decreasing. Starting from 170 beats/min or at the limit of about 200 beats/min the maximum rate fo oxygen consumption $\left(\mathrm{VO}_{2} \mathrm{max}\right)$ will probably be reached. After arrining at $\mathrm{VO}_{2} \max$ at $f_{H}$ over 200 beats $/ \mathrm{min}$ the upper anaerobic threshold is exceeded and already fully developed anaerobic energy metabolism is in progress. This finding corresponds to the observation of drastical elevation of lactate over this limit as was referred e. g. by Persson (1983) and others.

We can summarize that the parabolic dependence of the pulse oxygen value upon exercise intensity, heart frequency and oxygen uptake allows to assume that in horses at exercise $\mathrm{TO}_{2}$ represents an indirect index of $\mathrm{VO}_{2}$ and stroke volume $\left(Q_{8}\right)$ changes. Changes in $\mathrm{TO}_{2}$ during horse exercise thus correspond closely with those in $\mathrm{VO}_{2}, Q_{s}$ with the splenic red cell reserve mobilization and with fluid shift between intravasal and extravasal spaces at exercise. The elevation in $\mathrm{TO}_{2}$ is primarily conditioned by the increase of $\mathrm{VO}_{2}$ and by red cell mobilization, secondarily by the $Q_{s}$ increase. The limit of reaching $\mathrm{TO}_{2} \max$ is identical with that of $Q_{s} \max$ at working effort $\mathrm{WE}=70 \% \max$ and signalizes the arrival at the maximum rate of oxygen consumption $\left(\mathrm{VO}_{2} \mathrm{max}\right)$. The $\mathrm{TO}_{2}$ reduction is primarily conditioned by the $Q_{8}$ decrease and secondarily perhaps by the $\mathrm{VO}_{2}$ decrease. The drop of $Q_{s}$ is probably induced by an extreme shortening of diastolic filling time at heart rate over 200 beats $/ \mathrm{min}$. At higher exercise intensity the growing hemodynamic and oxygen requirements of a working organism are met by the mechanism of heart rate increase only.

\section{Vliv stupňované pohybové zátěže na některé kardiorespirační funkce sportovních koní}

U 12 koní při stupňované pohybové zátěži byla radiotelemetrickou metodou sledována srdeční frekvence $\left(f_{H}\right)$ a celkový minutový př́ijem kyslíku $\left(\mathrm{VO}_{2}\right)$. Z takto získaných hodnot byla stanovena hodnota tzv. tepového kysliku $\left(\mathrm{TO}_{2}\right)$, reprizentující množství $\mathrm{O}_{2}$ transportované jedním systolickým objemem srdečním. 
Závislost přijmu kyslíku na rychlosti pohybu i srdeční frekvenci je lineární. Pozitivní korelační vztah je dán velmi těsnými korelačními koeficienty $r(0,99$ a 0,97). Velikost tepového kyslíku je však $\mathrm{v}$ parabolické závislosti nejen na rychlosti pohybu, ale i na srdeční frekvenci a přijmu kyslíku do organismu. Nejprudší nárůst velikosti $\mathrm{T}_{2}$ je do $f_{H} 170$ tepů/min a rychlosti $500 \mathrm{~m} / \mathrm{min}$. Při spotřebě kyslíku vyšši jak $55 \mathrm{l} / \mathrm{min}$, který odpovídá pracovnímu úsili WE $70 \% \max$, se $\mathrm{TO}_{2}$ zmenšuje.

\section{Влияние үвеличивающейся двигательной нагрузки на некоторые сердечно-дыхательные фүнкции скаковых пошадей}

У 12 лошадей с увеличивающейся двигательной нагрузки с помощью телеметрического метода исследовали частоту пульса $\left(\mathrm{f}_{H}\right)$ и общий поминутный расход кислорода $\left(\mathrm{VO}_{2}\right)$. По полученным таким способом значениям определяли величину так называемого пульсионного кислорода $\left(\mathrm{TO}_{2}\right)$, представляющего количество транспортируемого $\mathrm{O}_{2}$ одним систолическим объемом сердца.

Зависимость расхода кислорода от скорости движения и частоты пульса является линейной. Позитивное корреляционное отношение дано весьма тесными коэффициентами корреляции $\mathbf{r}(0,99$ и 0,97$)$. Однако величина пульсионного кислорода находится в параболической зависимости не только от скорости движения, но и от частоты биения сердца и поступления кислорода в организм. Самый стремительный прирост величины $\mathrm{T0}_{2}$ наступает по $\mathrm{f}_{H} 170$ пульсаций/мин и при скорости 500 м/мин. При расходе кислорода, превышающем 55 л/мин и соответствующем трудовой нагрузке $\mathrm{WE} 70 \%$ макс, $\mathrm{T0}_{2}$ уменьшается.

\section{References}

CARLSON, G. P.: Thermoregulation, fluid and electrolyte balance. In: Equine Exercise Physiology. Snow, D. H., Persson, S. G. B., Rose, J. R. (Eds). Cambridge, Granta, Burlington Press 1983, pp. $291-309$.

CARLSON, G. P.: Hematology and body fluids in the equine athlete: A review. In: Equine Exercise Physiology 2. Gillespie, J. R., Robinson, N. E. (Eds). Davis, ICEEP Publications 1987, pp. $393-425$.

EHRLEIN, H. J.: Untersuchungen über die Herzschlagfrequenz als Maß für die Leistungsfähigkeit von Pferden. (Habil. Schrift.) Hannover 1970, 160 p.

ENGELHARDT, W.: Cardiovascular effects of exercise and training in horses. Adv. veter. Sci. comp. Med., 21, 1977: 173-204.

EVANS, D. L.-ROSE, J. R.: Maximum oxygen uptake in racehorses: changes with training state and prediction from submaximal cardiorespiratory measurements. In: Equine Exercise Physiology 2. Gillespie, J. R., Robinson, N. E. (Eds). Davis, ICEEP Publications 1987, pp. $52-67$.

FREGIN, G. F. - THOMAS, D. P.: Cardiovascular response to exercise in the horse: A review. In: Equine Exercise Physiology. Snow, D. H., Persson, S. G. B., Rose, J. R. (Eds). Cambridge, Granta, Burlington Press 1983, pp. 76-90.

GILLESPIE, J. R.: The role of the respiratory system during exertion. J. S. Afr. veter. Assoc., 45, 1974: 305-309.

GILLESPIE, J. R.: The role of the respiratory system during exertion. J. S. Afr. veter. Assoc., 1974: $305-309$.

GILLESPIE, J. R.-PASCOE, J. R.: Respiratory function in the exercising horse: A review In: Equine Exercise Physiology. Snow, D. H., Persson, S. G. B., Roce, J. R. (Eds). Cambridge, Granta, Burlington Press 1983, pp. 1-6.

HANAK, J. - ZAKOPAL, J.: The system of spiroergometry in equestrian horses in movement. In: Proc. 21st World veter. Congr., Moscow 1979, 6, p. 14. 
HANAK, J. - ZAKOPAL, J.: Systém kontroly zdraví v chovech spörtovních koní - systém elektrokardiografie a bioradiotelemetrie. (Project report). Brno 1980, $94 \mathrm{p}$.

HANÁK, J.: Bioradiotelemetrie a elektrokardiogram u koní při zátěži. (Habilitation Thesis.) Brno 1980, 192 p.

HANÁK, J.: Studium dynamiky metabolických procesů u sportovních a dostihových koní. (DrSc. Thesis). Brno 1987, $360 \mathrm{p}$.

HOLMES, J. R.: A superb transport system - The circulation. Equine veter. J., 14,1982: $267-276$.

HÖRNICKE, H.-MEIXNER, R.-POLLMANN, U.: Respiration in exercising horses. In: Equine Exercise Physiology. Snow, D. H., Presson, S. G. B., Rose, J. R. (Eds). Cambridge, Granta, Burlington Press 1983, p. 7-16.

McMIKEN, D. F.: An energetic basis of equine performance. Equine veter. J., 15, 1983: 123-133.

PERSSON, S. G. B.: On blood volume and working capacity in horses. Acta veter. scand., Suppl. $19,1967,189$ p.

PERSSON, S. G. B.: Blood volume, state of training and work capacity of race horses. Equine veter. J., 1, 1968: 52-62.

PERSSON, S. G. B.-EKMAN, L.-LYDIN, G.-TUFVESON, G.: Circulatory effect of splenectomy in the horse. 1. Effect on red cell distribution and variability of hematocrit in the peripheral blood. Zbl. Vet. Med., 20A, 1973a: 441-445.

PERSSON, S. G. B.-EKMAN, L.-LYDIN, G.-TUFVESON, G.: Circulatory effects of splenectomy in the horse. Effects on plasma volume and total and circulating red cell volume. Zbl. Vet. Med., 20A, 1973b: 246-268.

PERSSON, S. G. B.-BERGSTEN, G.: Circulatory effect of splenectomy in the horse. 4. Effect on blood flow and blood lactate at rest and during exercise. Zbl. Vet. Med., 20A, 1975: 801 -807.

PERSSON, S. G. B.: Evaluation of exercise tolerance and fitness in the performace horse. In: Equine Exercise Physiology. Snow, D. H., Persson, S. G. B., Rose, J. R. (Eds). Cambridge, Granta, Burlington Press 1983, p. 441-457.

PHYSICK-SHEARD, P. W.: Cardiovascular response to exercise and training in the horse. In: Veter. Clin. N. Amer. Equine Practice, 1, 1985, p. 383-417.

ROSE, J. R.-EVANS, D. L.: Cardiovascular and respiratory function in the athletic horse. In: Equine Exercise Physiology 2. Gillespie, J. R., Robinson, N. E. (Eds.). Davis, ICEEP Prublications 1987, p. $1-24$.

SENTA, T. - SMETZER, D. L.-SNITH, C. R.: Effects of exercise on certain electrocardiographic parameters and cardiac arrhythmias in the horse. Cornell Veter., 60, 1970: 552-569.

THOMAS, D. P.-FREGIN, G. F.: Cardiorespiratory and metabolic responses to treadmill exercise in the horse. J. appl. Physiol., 50, 1981: 864-868.

WASSERMAN, K. - WHIPP, B. J.: Exercise Physiology in health and disease. Amer. Rev. Resp. Disease, 112, 1975: 219-249.

WITTKE, G.-FRANKE, D.-KRZYWANEK, H.: Elektrolytkonzentrationen und Osmolarität der Blutplasmas von Trabrennpferden nach Wettkampfbelastung. Berl. Münch. tierärztl. Wschrm, 87, 1974: 425-428. 